\title{
Norma Sosiomatematik Ditinjau dari Minat Belajar Matematika Siswa
}

\author{
Silvi Anisa ${ }^{1 *}$, Nanang Supriadi ${ }^{2}$, Dona Dinda Pratiwi ${ }^{3}$ \\ 1,2,3 Universitas Islam Negeri Raden Intan Lampung \\ *silviannisa04@gmail.com
}

Diterima: Desember 2018. Disetujui: Februari 2019. Dipublikasikan: Juli 2019.

\begin{abstract}
ABSTRAK
Norma sosiomatematik merupakan sebuah norma sosial yang bernuansa matematika. Dengan norma sosiomatematika, kecerdasan yang dimiliki siswa dapat dikembangkan karena norma ini sangat terkait dengan negosiasi dan interaksi antar siswa dan interaksi siswa dengan guru. Namun norma sosiomatematik dapat dinyatakan baik dalam proses pembelajaran di dalam kelas jika minat belajar terhadap matematika yang dimiliki siswa juga baik, karena minat merupakan dorongan dari dalam diri seseorang tanpa ada yang memaksa. Tujuan dalam penelitian ini adalah untuk mengetahui bagaimanakah analisis norma sosiomatematik ditinjau dari minat belajar matematika. Penelitian ini merupakan penelitian jenis kualitatif dengan metode yang digunakan adalah deskriptif kualitatif. Data dalam penelitian ini berupa data norma sosiomatematik dan minat belajar matematika yang didapatkan dari hasil lembar obsevasi norma sosiomatematik, angket minat belajar matematika dan wawancara terhadap siswa kelas VIII-F. Penelitian ini menggunakan triangulasi teknik, yaitu mencocokkan data norma sosiomatematik dan minat belajar matematika melalui beberapa teknik yang berbeda, yaitu lembar observasi, angket dan wawancara. Berdasarkan hasil penelitian, 30 subjek penelitian memiliki rata-rata norma sosiomatematik diatas persentase $50 \%$ atau dapat dikatakan subjek penelitian tersebut memiliki norma sosiomatematik dalam kategori baik dan untuk minat belajar matematika juga menunjukan kategori baik dengan hasil rata-rata $62 \%$. Maka dapat disimpulkan bahwa norma sosiomatematik dapat dikatakan baik jika minat belajar terhadap pelajaran matematika juga baik.
\end{abstract}

Kata kunci: norma sosiomatematik, minat belajar matematika.

\begin{abstract}
Sociomatematic norms are a social norm that has mathematical nuances. With sociomatematic norms, intelligence possessed by students can be developed because this norm is closely related to negotiation and interaction between students and the interaction of students and teachers. But sociomatematic norms can be expressed both in the learning process in the classroom if the interest in learning about mathematics that is owned by students is also good, because interest is an encouragement from someone without being forced. The purpose of this study was to find out how the analysis of sociomatematic norms in terms of interest in learning mathematics. This research is a qualitative type of research with the method used is descriptive qualitative. The data in this study are sociomatematic normative data and mathematics learning interest obtained from the results of sociomatematic norms observation sheet, mathematics learning interest questionnaire and interviews with students of class VIII-F. This study uses triangulation techniques, which match the sociomatematic norm data and interest in learning mathematics through several different techniques, namely observation sheets, questionnaires and interviews. Based on the results of the study, 30 research subjects had the above average sociomatematic norms the percentage of 50\% or it can be said that the research subject had sociomatematic norms in the good category and for mathematics learning interest also showed a good category with an average yield of $62 \%$. Then it can be concluded that sociomatematic norms can be said to be good if the interest in learning about mathematics is also good.
\end{abstract}

Keywords: sociomatematic norms, interest in learning mathematics.

How to Cite: Anisa, S., Supriadi, N., \& Pratiwi, D. D. (2019). Norma Sosiomatematik Ditinjau dari Minat Belajar Matematika Siswa. Journal of Medives : Journal of Mathematics Education IKIP Veteran Semarang, 3(2), 153-164. 


\section{PENDAHULUAN}

Pendidikan mempunyai peran penting dalam kehidupan sehari-hari. Menurut Undang-Undang dijelaskan bahwa setiap penduduk berhak mendapatkan pendidikan yang bermutu. Pendidikan juga mempunyai peranan yang sangat penting dalam membangun sumber daya manusia yang berkualitas, karena pendidikan merupakan sarana untuk membentuk seseorang menjadi individu yang memiliki pengetahuan dan keterampilan (Rofiq, 2017).

Pendidikan merupakan ladang utama untuk memperoleh pengetahuan dan saran untuk menunjang intelektual setiap manusia yang memiliki keinginan untuk maju. Pendidikan pada hakikatnya merupakan usaha sadar untuk mengembangkan kepribadian dan kemampuan didalam dan di luar sekolah dan berlangsung semuar hidup. Dengan kata lain, pendidikan adalah proses dalam rangka mempengaruhi siswa upaya menyesuaikan diri sebaik mungkin dengan lingkungannya, dan dengan demikian akan menimbulkan perubahan dalam kehidupan masyarakat (Hamalik, 2010).

Matematika merupakan bagian dari ilmu pengetahuan yang turut memberikan sumbangan yang signifikan terhadap perkembangan ilmu pengetahuan sumber daya manusia. Perkembangan ilmu pengetahuan dan teknologi tidak lepas dari dukungan dan peranan matematika. Matematika merupakan mata pelajaran yang penting. Setidaknya hal itu bisa terlihat dari jam mata pelajaran matematika di sekolah yang mendapat porsi lebih banyak dibandingkan pelajaran lainnya. Matematika merupakan ilmu yang sangat berperan penting dalam kehidupan dan merupakan cabang ilmu yang bermanfaat untuk terjun dan bersosioalisasi di masyarakat (Purwanti, Pratiwi, \& Rinaldi, 2016).

Matematika juga mempunyai peran penting dalam berbagai disiplin ilmu dan pengembangan daya pikir manusia. Pelajaran matematika merupakan pelajaran yang sulit dan menakutkan adalah hal yang cukup beralasan. Hal tersebut membuat sebagian siswa kurang menyukai pelajaran matematika. Pembelajaran matematika merupakan suatu mata pelajaran yang harus didasari rasa ingin tahu dan didukung minat belajar (Suherman, 2015).

Minat ialah suatu rasa lebih suka dan rasa ketertarikan pada suatu hal, tanpa ada yang menyuruh. Minat dapat dikatakan suatu yang tumbuh dari dalam diri siswa untuk melakukan keinginannya tanpa ada perantara yang lain. Sedangkan Hilgard (dalam Slameto) memberi rumusan tentang minat adalah sebagai berikut. "Interest is persisting tendency to pay attention to and enjoy some activity or content". Minat adalah kecenderungan yang tetap untuk memperhatikan dan mengenang beberapa kegiatan. Kegiatan yang diminati seseorang, diperhatikan terus-menerus yang disertai dengan rasa senang (Slameto, 2013).

Minat merupakan alat motivasi pokok bagi siswa untuk berusaha dalam belajar. Jadi apabila siswa merasa tertantang dan memiliki minat yang besar untuk mempelajari matematika, siswa akan terdorong agar berada dalam kondisi yang memungkinkan dirinya 
untuk menyalurkan minatnya dan berusaha menghilangkan atau mengabaikan faktor yang menghalanginya untuk belajar. Proses pembelajaran di sekolah, hendaknya siswa memiliki minat belajar yang tinggi terhadap pelajaran yang diikuti. Kurangnya minat belajar menyebabkan kurangnya perhatian, partisipasi, dan usaha dalam proses pembelajaran. Akibat dari kurangnya minat belajar tentunya akan berdampak buruk pada hasil yang akan dicapai. Minat belajar matematika adalah bentuk kecenderungan dan ketertarikan terhadap mata pelajaran matematika, yang dilandasi oleh perasaan senang dan bahagia terhadap mata pelajaran matematika untuk mendapatkan perubahan tingkah laku yang diperoleh siswa dari sebuah pengalaman secara individu.

Hal di atas terjadi juga di SMP N 24 Bandar lampung, bahwa minat belajar siswa sangat kurang. Hal ini terlihat ketika guru meminta siswa untuk mengerjakan soal yang diberikan, hanya beberapa siswa yang mengerjakan sedangkan siswa yang lain tidak mengerjakan dan tidak berminat untuk mencari penyelesaian dari soal tersebut dan lebih senang menunggu teman atau guru menyelesaikan soal tersebut. Ketika guru mengajukan pertanyaan mengenai materi, siswa tidak menjawab dengan baik. Jika guru meminta siswa untuk menjawab pertanyaan secara lisan, mereka hanya terdiam dan tidak akan menjawab hingga guru memanggil nama mereka. Pada saat guru membahas materi yang dipelajari, siswa tidak memperhatikan dan asyik mengobrol bercanda, dan sibuk masing-masing.
Berdasarkan pernyataan di atas terlihat bahwa minat belajar siswa masih sangat kurang, maka seorang guru harus bisa menumbuhkan minat belajar siswa dengan metode-metode yang membantu siswa lebih aktif. Dalam menumbuhkan minat belajar perlu adanya suatu metode yang digunakan salah satunya norma sosiomatematik. Norma sosiomatematik adalah suatu kaidah atau aturan yang terbentuk dari suatu kultur sosial dalam proses pembelajaran matematika. Norma sosiomatematik terkait dengan hubungan individu, matematika dan masyarakat yang terbentuk dalam kelas matematika (Kadir, 2008).

Norma sosiomatematik berkaitan dengan bagaimana siswa menyakini dan memahami pengetahuan matematika, menempatkan diri dalam situasi sosial dalam membangun pengetahuan matematika (Rizkianto, 2013). Norma sosiomatematik di kelas itu bersifat fleksibel, dimana guru, siswa dapat menjadi agen dalam proses pembentukannya. Norma sosiomatematik tidak hanya berdampak positif terhadap peningkatan prestasi akademik siswa tetapi juga norma sosiomatematik berperan dalam pengembangan kepribadian siswa (Sulfikawati, Suharto, \& Kurniati, 2016).

Namun pada kenyataannya tidak sesuai dengan harapan. Terkadang banyak siswa yang malu bertanya, malas untuk memberikan argumen dikarenakan minat belajar siswa yang rendah. Oleh karena itu, peran guru dan siswa dalam menciptakan norma sosiomatematik sangat penting dan hal itu harus dilandasi minat belajar yang tinggi. Proses pembelajaran merupakan rangkaian 
kegiatan komunikasi antara siswa dan guru. Proses pembelajaran dikatakan efektif apabila terjadi transfer belajar yaitu materi yang disajikan guru dapat diserap ke dalam struktur kognitif siswa. Seperti hubungan timbal balik dari aktivitas norma sosiomatematik yang dilakukan guru selama proses pembelajaran untuk meningkatkan minat belajar matematika maka siswa juga dapat memberikan respon yang baik. Adapun respon berupa aktivitas yang dapat dilakukan siswa dalam melaksanakan norma sosiomatematik di kelas, yaitu: siswa saling mengajukan pertanyaan yang menekankan pada penalaran matematika, klarifikasi dan pemahamanan untuk meningkatkan minat belajar siswa, siswa menjelaskan solusi yang mereka miliki menggunakan argumen matematis, siswa mencapai kesepakatan menggunakan penalaran dan bukti matematis dan siswa membandingkan strategi yang mereka miliki untuk menemukan persamaan dan perbedaan yang penting secara matematis (Utari, 2017).

Norma sosiomatematik terkait dengan hubungan individu, matematika, dan masyarakat yang terbentuk dalam kelas matematika, maka norma sosiomatematik juga terkait dengan pembelajaran matematika. Soedjadi menyatakan, dalam pembelajaran matematika terdapat beberapa nilai, yaitu: kerjasama, disiplin, kebebasan, bebas berpendapat, cermat-tekun, menerima pendapat, sikap hormat, dan kesepahaman.

Menurut Herbel-Eisenman norma sosiomatematik memfokuskan pada kebenaran, peran, tanggung jawab, dan harapan yang satu sama lain dinegosiasikan antara guru dan siswa. Hal ini bertujuan untuk menguji bagaimana norma ditempatkan melalui cerita dikelas. Norma sosiomatematik tersebut tersusun berdasarkan nilai-nilai matematika dan pembelajaran matematika di kelas, yaitu kebenaran, peran, tanggung jawab, harapan, kerjasama, disiplin, kebebasan, bebas berpendapat, cermat-tekun, menerima pendapat, sikap hormat, kesepahaman, kesepakatan, konsistensi, kesemestaan, dan ketat. Norma sosiomatematik adalah suatu kaidah atau aturan yang terbentuk dari suatu kultur sosial dalam proses pembelajaran matematika (Kadir, 2008).

Norma sosiomatematik berkaitan dengan bagaimana siswa menyakini dan memahami pengetahuan matematika, menempatkan diri dalam situasi sosial dalam membangun pengetahuan matematika (Rizkianto, 2013). Menurut Seon Mi \& Mi Kyeong menyatakan $a$ sociomathematical norm is the consideration of a mathematically acceptable explatanation in conjuction with an understanding of what has been mathematically different. Artinya norma sosiomatematik adalah mempertimbangkan suatu penjelasan secara sistematis yang dapat diterima bersamaan dengan pemahaman tentang apa yang secara sistematis berbeda (Dewi Fitriana, 2018).

Norma sosiomatematik, secara khusus dikaitkan pada argumentasi secara matematika, yaitu bagaimana pembelajar melakukan proses interaksi dan negosiasi untuk memahami konsepkonsep matematika. Yackel \& Cobb menyebutkan bahwa "pemahaman 
tentang argumentasi seperti apa yang bisa diterima secara matematis" merupakan contoh dari norma sosiomatematik. NCTM merumuskan standar komunikasi untuk menjamin kegiatan pembelajaran matematika yang mampu mengembangkan kemampuan siswa dalam: (1) menyusun dan memadukan pemikiran matematika melalui komunikasi, (2) mengkomunikasikan pemikiran matematika secara logis dan sistematis kepada sesama siswa, kepada guru, maupun orang lain, (3) menganalisis dan mengevaluasi pemikiran dan strategi matematis orang lain, dan (4) menggunakan bahasa matematika untuk mengekspresikan ide matematika secara tepat. Kemampuan komunikasi ini tentunya ditunjang dari pengadaan masalah matematika yang menantang (challenging problem).

Masalah matematika yang digunakan bersifat terbuka (open-ended) sehingga mendukung terjadinya diskusi antar siswa. Karakteristik masalah yang terbuka akan memicu pada terjadinya interpretasi masalah dan strategi penyelesaian. Perbedaan tersebut selanjutnya menjadi objek diskusi siswa untuk merumuskan suatu kesepakatan dan pemahaman bersama (Rizkianto, 2013).

Ariyadi menyatakan bahwa norma sosiomatematik merupakan suatu aturan eksplisit maupun implisit yang mempengaruhi partisipasi siswa dalam aktivitas matematika. Norma sosiomatematik berkaitan dengan bagaimana siswa meyakini dan memahami pengetahuan matematika, menempatkan diri dalam suatu interaksi sosial dalam membangun pengetahuan matematika. Secara khusus,
Lopez membedakan norma sosiomatematik menjadi dua, yaitu: (1) Norma sosiomatematik terkait dengan proses pemecahan masalah. Norma ini fokus pada ekspektasi bagaimana pemecahan masalah harus dilakukan. Sebagai contoh adalah mencoba berbagai macam strategi pemecahan masalah dan verifikasi hasil penyelesaian. (2) Norma sosiomatematik terkait dengan partisipasi dalam aktivitas bersama untuk pemecahan masalah. Norma ini fokus pada bentuk ideal interaksi sosial yang diharapkan dapat mendukung aktivitas penyelesaian masalah secara produktif. Norma sosiomatematik tidak hanya berdampak positif terhadap peningkatan prestasi akademik siswa tetapi juga norma sosiomatematik berperan dalam pengembangan kepribadian siswa (Wijaya, 2009).

Minat sangat besar pengaruhnya terhadap proses belajar siswa, karena bila bahan pelajaran yang dipelajari tidak sesuai dengan minat siswa, maka siswa tidak akan belajar dengan baik, dan semangat, karena tidak ada minat atau daya tarik dalam diri siswa untuk belajar. Minat belajar siswa memiliki pengaruh terhadap pembelajaran matematika, dimana minat dapat menumbuhkan rasa ingin tahu siswa terhadap matematika. Minat pada dasarnya merupakan rasa ketertarikan terhadap sesuatu dan selalu ingin terus menerus melakukan hal tersebut. Sehingga minat dapat diekspreksikan melalui pernyataan yang menunjukan bahwa siswa lebih menyukai suatu hal itu dari pada hal yang lainnya, dapat pula melalui partisipasi dalam suatu aktivitas 
kegiatan. Pembelajaran matematika yang dilakukan di kelas berupa aktivitasaktivitas telah menggunakan norma sosiomatematik.

Adapun aktivitas yang dapat dilakukan guru dalam melaksanakan norma sosiomatematik di kelas seperti, menggiring siswa untuk bertanya dan berargumentasi selama proses pembelajaran, menciptakan suasana belajar yang kreatif dan inovatif, disertai menggunakan metode-metode pembelajaran yang membantu siswa lebih aktif. Seperti hubungan timbal balik dari aktivitas norma sosiomatematik yang dilakukan guru selama proses pembelajaran untuk meningkatkan minat belajar matematika maka siswa juga dapat memberikan respon yang baik. Adapun respon berupa aktivitas yang dapat dilakukan siswa dalam melaksanakan norma sosiomatematik di kelas, yaitu: siswa saling mengajukan pertanyaan yang menekankan pada penalaran matematika, klarifikasi dan pemahamanan untuk meningkatkan minat belajar siswa, siswa menjelaskan solusi yang mereka miliki menggunakan argumen matematis, siswa mencapai kesepakatan menggunakan penalaran dan bukti matematis dan siswa membandingkan strategi yang mereka miliki untuk menemukan persamaan dan perbedaan yang penting secara matematis (Utari, 2017). Adapun indikator norma sosiomatematik dalam pembelajaran matematika sebagai berikut. (1) Siswa mampu menerima berbagai keragaman tingkat berpikir dengan tidak merasa tinggi hati atau rendah diri. (2) Siswa menyepakati dalam menuliskan solusi permasalahan.
(3) Siswa mampu mengungkapkan ide/pendapat secara lisan untuk mencapai kesepakatan menggunakan bukti matematis. (4) Siswa mampu mengungkapkan solusi secara lisan untuk mencapai kesepakatan permasalahan. (5) Siswa mampu mengungkapkan ide/pendapat secara lisan dengan sistematis menggunakan bahasa yang dapat dimengerti (Sulfikawati et al., 2016).

Maka norma sosiomatematik adalah suatu peraturan yang diterapkan ketika proses interaksi selama pembelajaran matematika. Adapun interaksi yang diamati dalam penelitian ini adalah interaksi antar siswa ketika bekerja sama menyelesaikan masalah matematika. Ada dua elemen penting dalam proses interaksi yang akan mempengaruhi baik buruknya jalinan interaksi tersebut, yakni komunikasi matematik dan keterampilan sosial.

Berdasarkan penjelasan tersebut norma sosiomatematik berkaitan dengan minat, karena minat merupakan alat motivasi pokok bagi siswa untuk berusaha dalam belajar. Jadi apabila siswa merasa tertantang dan memiliki minat yang besar untuk mempelajari matematika, siswa akan terdorong agar berada dalam kondisi yang memungkinkan dirinya untuk menyalurkan minatnya dan berusaha menghilangkan atau mengabaikan faktor yang menghalanginya untuk belajar. Proses pembelajaran di sekolah, hendaknya siswa memiliki minat belajar yang tinggi terhadap pelajaran yang diikuti. Kurangnya minat belajar menyebabkan kurangnya perhatian, partisipasi dan usaha dalam proses pembelajaran, akibat 
dari kurangnya minat belajar tentunya akan berdampak buruk pada hasil yang akan dicapai.

Adapun rumusan masalah dalam penelitian ini adalah bagaimana deskripsi norma sosiomatematik yang ditinjau dari minat belajar matematika. Tujuan penelitan yang dilakukan untuk melihat norma sosiomatematik yang dimiliki siswa ditinjau dari minat belajar terhadap matematika. Manfaat dari penelitian ini memberikan solusi cara berinteraksi yang baik terhadap guru dan siswa lain dalam pembelajaran sehinnga suasana kelas semakin aktif dan bersemangat.

\section{METODE PENELITIAN}

Penelitian ini merupakan penelitian deskriptif dengan pendekatan kualitatif. Instrumen pengumpulan data yang digunakan adalah lembar anget minat belajar, lembar observasi norma sosiomatematik, dan pedoman wawancara. Subjek penelitian ini adalah siswa kelas VIII-F SMPN 24 Bandar Lampung yang berjumlah 30 siswa. Teknik pengambilan sampel dalam penelitian ini menggunakan purposive. Teknik pengumpulan data yang digunakan ialah observasi, angket, wawancara dan dokumentasi. Sebelum memulai aktivitas wawancara terlebih dahulu subjek penelitian dikategorikan berdasarkan data hasil norma sosiomatematik dan minat belajar matematika sebagai subjek dalam penelitian ini untuk diwawancarai lebih mendalam mengenai norma sosiomatematik dan minat belajar matematika. Teknik yang digunakan peneliti dalam menganalisis data adalah teknik model Miles and Huberman. Miles and Huberman mengemukakan bahwa aktivitas dalam analisis data kualitatif dilakukan secara interaktif dan berlangsung secara terus-menerus sampai tuntas, sehingga datanya sudah jenuh.

Dalam penelitian ini dilakukan pendeskripsian mengenai norma sosiomatematik yang ditinjau dari minat belajar matematika siswa.

\section{HASIL DAN PEMBAHASAN}

Observasi yang dilakukan terhadap siswa bertujuan untuk mengetahui norma sosiomatematik yang ada di dalam kelas. Berdasarkan hasil data lembar observasi norma sosiomatematik, bahwasanya setiap siswa memiliki norma sosiomatematik, hanya saja setiap siswa memiliki tingkat norma sosiomatematik yang berbeda-beda, yakni sangat baik, baik, dan cukup baik. Siswa yang memiliki norma sosiomatematik sangat baik sebanyak 7 siswa, 18 siswa memiliki norma sosiomatematik baik, dan 5 siswa memiliki norma sosiomatematik yang cukup baik. Hasil dari keseluruhan data tersebut dapat disimpulkan bahwa norma sosiomatematik yang dimiliki siswa menunjukan kategori baik, hal ini berdasarkan data hasil lembar observasi menujukan bahwa frekuensi norma sosiomatematik kategori baik lebih banyak dibandingkan frekuensi kategori sangat baik, dan cukup baik.

Angket yang dilakukan terhadap siswa bertujuan untuk mengetahui minat belajar matematika siswa. Berdasarkan hasil data angket minat belajar matematika, bahwasanya diperoleh 
frekuensi dari kategori minat belajar matematika tertinggi ada 6 siswa, frekuensi minat belajar matematika sedang ada 20 siswa dan kategori frekuensi minat belajar matematika ada 4 siswa. Hasil dari keseluruhan data dapat disimpulkan bahwa minat belajar matematika yang dimiliki siswa menunjukan kategori sedang, hal ini berdasarkan hasil data angket menujukan bahwa frekuensi minat belajar matematika kategori sedang lebih banyak dibandingkan frekuensi kategori tinggi dan rendah.

Berdasarkan hasil penelitian yang telah dilakukan diperoleh data berupa angket dan lembar observasi yang kemudian diolah mengunakan skala likert untuk melihat secara mendalam bagaimana norma sosiomatematik dan minat belajar matematika yang dimilliki subjek penelitian. Berdasarkan perhitungan yang dilakukan menggunakan skala likert dapat disimpulkan bahwa subjek penelitian norma sosiomatematik dimiliki subjek penelitian termasuk kedalam kategori baik, dengan norma sosiomatematik yang dimiliki subjek penelitian di atas rata-rata $50 \%$ yaitu $67,5 \%$, sedangkan untuk minat belajar matematika juga termasuk kedalam kategori baik, dengan hasil pengumpulan data yaitu $62 \%$.

Berdasarkan hasil wawancara yang dilakukan terhadap 6 subjek penelitian sebagai sampel dalam penelitian ini, setelah melalui berbagai pertimbangan dan berdasarkan hasil lembar observasi norma sosiomatematik dan angket minat belajar matematika diperoleh hasil wawancara sebagai berikut.
Hasil Wawancara Subjek Penelitian T

Berdasarkan hasil wawancara, subjek penelitian $\mathrm{T} 1$ dan $\mathrm{T} 2$ memiliki antusiasme yang baik dalam proses pembelajaran, menerima keragaman individu lainnya, mampu mengungkapkan ide atau tanggapan dengan bahasa yang baik dan jelas, mampu menuliskan ide secara matematis, memperhatikan dan mendengarkan guru pada saat menjelaskan materi, mampu menelaah kembali materi yang diajarkan, berinteraksi dengan baik kepada siswa yang lain, mengikuti pelajaran dengan baik, memberikan dukungan, motivasi dan bantuan kepada siswa yang mengalami kesulitan dan menerima kesepakatan bersama. Maka dapat disimpulkan subjek penelitian T1 dan T2 memiliki norma sosiomatematik yang sangat baik hal ini tentu didukung dengan minat belajar matematika yang tinggi.

\section{Hasil Wawancara Subjek Penelitian S}

Berdasarkan hasil wawancara di atas, dapat diketahui bahwa subjek penelitian S1 dan S2 memiliki antusiasme yang baik dalam mengerjakan tugas individu maupun kelompok, menerima individu lain dengan baik, memberikan ide atau tanggapan jika sedang mood, menggunakan bahasa yang baik dan jelas ketika memberikan argumen, memperhatikan dan mendengarkan apa yang dijelaskan guru, tapi tidak selalu bisa menyimpulkan kembali apa yang dijelaskan guru, berinterasi dengan baik, mengikuti pelajaran hingga akhir, memberikan dukungan atau bantuan kepada siswa yang lain. Serta menerima keputusan bersama. Maka dapat disimpulkan 
bahwa subjek penelitian S1 dan S2 memiliki norma sosiomatematik yang baik hal ini dikarenakan minat belajar kategori seangi terhadap matematika.

\section{Hasil Wawancara Subjek Penelitian R}

Berdasarkan hasil wawancara, norma sosiomatematik dengan ketegori minat belajar rendah yang dimiliki subjek penelitian R1 daan R2 dapat terlihat dari lebih senang mengerjakan tugas kelompok, menerima teman dengan cukup baik, mendengarkan dan memperhatikan guru walaupun tidak mengerti materinya, tidak mampu mengungkapkan ide dan menuliskan informasi penting pada materi yang dipelajari, berinteraksi dengan cukup baik, tidak membantu teman karena subjek penelitian R1 lebih sering meminta bantuan siswa lain, mengikuti pelajaran sampai selesai dengan perasaan bosan, namun menerima kesepakatan bersama. Maka dapat disimpulkan bahwa subjek penelitian R1 dan R2 memiliki norma sosiomatematik yang cukup baik dalam proses pembelajaran walaupun minat belajar yang dimiliki subjek penelitian R1 kurang.

Adapun hasil pembahasan dari subjek penelitian tentang norma sosiomatematik ditinjau dari minat belajar matematika dapat diuraikan sebagai berikut.

\section{Hasil yang Diperoleh Subjek Penelitian T}

Berdasarkan hasil penelitian diperoleh bahwa, subjek penelitian T1 dan T2 memiliki norma sosiomatematik yang sangat baik, hal ini terlihat dari cara subjek penelitian $\mathrm{T} 1$ dan $\mathrm{T} 2$ berinteraksi dengan guru dan siswa di dalam kelas saat proses pembelajaran matematika sedang berlangsung di sekolah. Subjek penelitian $\mathrm{T} 1$ dan $\mathrm{T} 2$ memiliki keyakinan positif terhadap pembelajaran matematika, mampu menunjukan antusiasme dalam pembelajaran matematika dengan perasaan senang, mampu menerima keragaman dengan tidak merasa rendah diri atau tinggi hati, mampu mengungkapkan ide atau tanggapan dengan menggunakan bahasa yang baikdan dapat dimengerti atau jelas, mampu mengungkapkan ide atau tanggapan dengan sistematis, mendengarkan dan memperhatikan guru, dan mampu berinteraksi dengan seluruh siswa dalam kelas, hal ini juga ditunjang dengan minat belajar yang tinggi dari subjek penelitian T1 dan T2. Maka dapat disimpulkan bahwa subjek penelitian yang memiliki minat belajar yang tinggi akan memiliki norma sosiomatematik yang sangat baik.

Hasil penelitian yang dilakukan oleh Rofiq (2017) menunjukan bahwa norma sosiomatematik merupakan suatu keyakinan yang berkaitan dengan interaksi dan keyakinan positif terhadap aktivitas pembelajaran matematika di dalam kelas, sehingga aktivitas pembelajaran di dalam kelas menjadi lebih aktif tidak pasif. Subjek penelitian T1 dan T2 memiliki keyakinan positif dan interaksi yang sangat baik dan siswa yang memiliki kemampuan menyelesaikan masalah secara mandiri tanpa bantuan guru atau teman, mampu mengungkapkan ide atau tanggapan dengan menggunakan bahasa yang sangat baik, jelas dan dimengerti, 
mampu menuliskan informasi penting dalam proses pembelajaran, memiliki rasa solidaritas yang tinggi terhadap siswa lain dan juga memiliki minat yang tinggi terhadap matematika.

\section{Hasil yang Diperoleh Subjek Penelitian S}

Berdasarkan hasil penelitian diperoleh bahwa, subjek penelitian S1 dan S2 memiliki norma sosiomatematik yang baik, hal ini terlihat dari interaksi dan keterlibatan subjek penelitian S1 dan S2 dengan guru dan siswa lainnya, mampu menunjukan antusiasme dalam pembelajaran matematika dengan perasaan senang, mampu menerima keragaman dengan tidak merasa rendah diri atau tinggi hati, mampu mengungkapkan ide atau tanggapan dengan menggunakan bahasa yang cukup baik dan dapat dimengerti atau jelas, mampu mengungkapkan ide atau tanggapan dengan sistematis, mendengarkan dan memperhatikan guru, dan mampu berinteraksi dengan seluruh siswa dalam kelas, hal itu terlihat dari subjek penelitian S1 dan S2 memiliki keyakinan sedang terhadap pembelajaran matematika tentu harus dibantu dengan minat belajar namun subjek $\mathrm{S} 1$ dan S2 masih kurang memahami dan mengetahui pembelajaran matematika dikarenakan minat belajar matematika yang sedang.

Hal yang sama juga diteliti oleh Sulfikawati (2016) hasilnya menunjukan bahwa siswa yang memiliki kemampuan mengungkapkan ide atau tanggapan tapi masih mengunakan bahasa terkadang sulit dimengerti, memiliki kemampuan menyelesaikan permasalahan secara mandiri namun terkadang juga membutuhkan bantuan teman atau guru untuk menyelesaikan permasalahan, menerima keragaman dan kesepakatan bersama. Hal ini terdapat di dalam kriteria subjek penelitian S1 dan S2 yang juga memiliki minat belajar matematika kategori sedang.

\section{Hasil yang Diperoleh Subjek Penelitian R}

Berdasarkan hasil penelitian diperoleh bahwa, subjek penelitian R1 dan R2 memiliki norma sosiomatematik yang cukup, hal ini terlihat dari interaksi dan keterlibatan subjek penelitian R1 dengan guru dan siswa lainnya. Subjek penelitian R1 dan R2 memiliki keyakinan negatif terhadap pembelajaran matematika hal itu tentu harus dilihat dari minat belajar matematika. Subjek R1 dan R2 kurang mampu menunjukan antusiasme dalam pembelajaran matematika dengan perasaan senang, mampu menerima keragaman dengan tidak merasa rendah diri atau tinggi hati, kurang mampu mengungkapkan ide atau tanggapan dengan menggunakan bahasa yang baik dan dapat dimengerti atau jelas, kurang bisa mengungkapkan ide atau tanggapan dengan sistematis, subjek penelitian R1 dan R2 mendengarkan dan memperhatikan guru, dan mampu berinteraksi dengan seluruh siswa dalam kelas dan masih kurang dalam memahami matematika dikarenakan minat belajar matematika yang rendah. Sehingga proses pembelajaran yang terjadi di dalam kelas tidak barjalan dengan baik.

Hasil yang sama dengan penelitian oleh Rofiq (2017) mengungkapkan 
siswa yang tidak memiliki kemampuan menyelesaikan permasalahan secara mandiri harus membutuhkan bantuan teman atau guru untuk menyelesaikan permasalahan, tidak mampu mengungkapkan ide atau tanggapan dengan bahasa yang cukup baik, jelas dan mudah dimengerti, kurang memotivasi dan memberi dukungan kepada siswa lain. Hal ini terdapat di dalam kriteria subjek penelitian R1 dan R2 yang juga memiliki minat belajar matematika kategori rendah.

Berdasarkan pembahasan dari masing-masing subjek penelitian dapat disimpulkan bahwa subjek penelitian yang memiliki minat belajar yang tinggi pasti memilki norma sosiomatematik yang sangat baik, subjek penelitian yang memiliki minat belajar yang sedang pasti memilki norma sosiomatematik yang baik, subjek penelitian yang memiliki minat belajar yang rendah pasti memilki norma sosiomatematik yang cukup, hal ini terlihat berdasarkan hasil penelitian yang dilakukan peneliti.

Sebagaimana yang telah peneliti jelaskan dan paparkan mengenai hasil penelitian dari analisis norma sosiomatematik ditinjau dari minat belajar matematika siswa, peneliti mengharapkan bahwa hasil penelitian ini bermanfaat dan bisa dijadikan sebagai bahan referensi bagi peneliti yang lain maupun sebagai sumbangan pemikiran bagi instansi pendidikan.

\section{DAFTAR PUSTAKA}

Dewi Fitriana. (2018). Peran Media ELearning Dalam Pembelajaran Untuk Mengoptimalkan Kemampuan Literasi Matematika dan Norma Sosiomatematik. In Program Studi Pendidikan Guru Sekolah Dasar Program Studi Pendidikan Matematika Universitas Muria Kudus (pp. 58-62).

Hamalik, O. (2010). Kurikulum dan Pembelajaran. (P. B. Aksara, Ed.). Jakarta.

Kadir. (2008). Mengembangkan Norma Sosiomatematik (Sociomathematical Norms) Dengan Memanfaatkan Potensi Lokal Dalam Pembelajaran Matematika. Pythagoras, 4(1), 74-85.

Purwanti, R. D., Pratiwi, D. D., \& Rinaldi, A. (2016). Pengaruh Pembelajaran Berbatuan Geogebra terhadap Pemahaman Konsep Matematis ditinjau dari Gaya Kognitif. Al-Jabar: Jurnal Pendidikan Matematika, 7(1), 115-122.

Rizkianto, I. (2013). Norma sosiomatematik dalam kelas matematika. In $P-42$ (pp. 978-979).

Rofiq, A. N. (2017). Analisis Norma Sosiomatematik Dalam Pembelajaran Kolaboratif Pokok Bahasan Persamaan Linier Satu Variabel Kelas VII-B SMP Negeri 4 Jember.

Slameto. (2013). Belajar \& Faktor-Faktor Yang Mempengaruhinya. (R. Cipta, Ed.). Jakarta.

Suherman. (2015). Kreativitas Siswa Dalam Memecahkan Masalah Matematika Materi Pola Bilangan dengan Pendekatan Matematika Realistik (PMR) Suherman. Al-Jabar: Jurnal Pendidikan Matematika, 6(1), 81-90.

Sulfikawati, D., Suharto, \& Kurniati, D. (2016). Analisis Norma Sosiomatematik dalam Pembelajaran Kolaboratif Pokok Bahasan Segitiga dan Segiempat di Kelas VII-C SMP Negeri 11 Jember 
164 | Silvi Anisa, Nanang Supriadi, Dona Dinda Pratiwi - Norma Sosiomatematik Ditinjau dari Minat Belajar Matematika Siswa

Sociomathematical Norms Analysis in Collaborative Learning in Triangle and Quadrilateral Topic at VII-C of Junior High. Jurnal Edukasi UNEJ, 3(3), 1-4.

Utari, R. S. (2017). Implementasi Nilai-Nilai Karakter dan Norma Sosiomatematik dalam Pembelajaran Matematika. Prosiding Seminar Nasional Pendidikan Program Pascasarjana Universitas PGRI Palembang, Palembang, 25 November 2017 (pp. 151-156).

Wijaya, A. (2009). Permainan (Tradisional) untuk Mengembangkan Interaksi Sosial,
Norma Sosial dan Norma Sosiomatematik pada Pembelajaran Matematika dengan Pendekatan Matematika Realistik. 